\title{
B cell analysis of ethnic groups in Mali with differential susceptibility to malaria
}

\author{
Silvia Portugal', Didier Doumtabe², Boubacar Traore², Louis H Miller ${ }^{3}$, Marita Troye-Blomberg ${ }^{4}$, \\ Ogobara K Doumbo ${ }^{2}$, Amagana Dolo², Susan K Pierce ${ }^{1}$ and Peter D Crompton ${ }^{1 *}$
}

\begin{abstract}
Background: Several studies indicate that people of the Fulani ethnic group are less susceptible to malaria compared to those of other ethnic groups living sympatrically in Africa, including the Dogon ethnic group. Although the mechanisms of this protection remain unclear, the Fulani are known to have higher levels of Plasmodium falciparum-specific antibodies of all Ig classes as compared to the Dogon. However, the proportions of B cell subsets in the Fulani and Dogon that may account for differences in the levels of Ig have not been characterized.
\end{abstract}

Methods: In this cross-sectional study, venous blood was collected from asymptomatic Fulani $(n=25)$ and Dogon $(n=25)$ adults in Mali during the malaria season, and from P. falciparum-naïve adults in the U.S. $(n=8)$. At the time of the blood collection, P. falciparum infection was detected by blood-smear in $16 \%$ of the Fulani and $36 \%$ of the Dogon volunteers. Thawed lymphocytes were analysed by flow cytometry to quantify B cell subsets, including immature and naïve B cells; plasma cells; and classical, activated, and atypical memory B cells (MBCs).

Results: The overall distribution of B cell subsets was similar between Fulani and Dogon adults, although the percentage of activated MBCs was higher in the Fulani group (Fulani: 11.07\% [95\% Cl: 9.317 - 12.82]; Dogon: 8.31\% [95\% Cl: 6.378 - 10.23]; P = 0.016). The percentage of atypical MBCs was similar between Fulani and Dogon adults (Fulani: 28.3\% [95\% Cl: 22.73 - 34.88]; Dogon: 29.3\% [95\% Cl: 25.06 - 33.55], but higher than U.S. adults (U.S.: 3.0\% [95\% Cl: $-0.21-6.164] ; \mathrm{P}<0.001)$. Plasmodium falciparum infection was associated with a higher percentage of plasma cells among Fulani (Fulani infected: 3.3\% [95\% Cl: 1.788 - 4.744]; Fulani uninfected: 1.71\% [95\% Cl: $1.33-2.08] ; P=0.011)$, but not Dogon adults.

Conclusion: These data show that the malaria-resistant Fulani have a higher percentage of activated MBCs compared to the Dogon, and that $P$. falciparum infection is associated with a higher percentage of plasma cells in the Fulani compared to the Dogon, findings that may account for the higher levels of $P$. falciparum antibodies in the Fulani.

\section{Background}

Several studies have demonstrated that individuals of the Fulani ethnic group in West Africa are at lower risk of malaria and tend to have lower Plasmodium falciparum parasite densities compared to individuals of other ethnic groups living sympatrically with the Fulani, including the Dogon [1]. Although protective mechanisms among the Fulani remain unclear, many investigators have consistently shown that the Fulani have higher levels of antibodies

\footnotetext{
* Correspondence: pcrompton@niaid.nih.gov

'Laboratory of Immunogenetics, National Institute of Allergy and Infectious

Diseases, National Institutes of Health, Rockville, MD 20852, USA

Full list of author information is available at the end of the article
}

specific for $P$. falciparum antigens expressed at the liver and blood stages [1-5], and enhanced IgG1 and IgG3 subclass and IgM antibody responses to malaria [6]. The B cell biology underlying these observations is not understood.

It is now well established that long-term antibody responses require the generation and maintenance of memory-B cells (MBCs) and long-lived plasma cells (LLPCs), defined in humans by the cell surface markers $\mathrm{CD} 19^{+} \mathrm{CD} 27^{+} \mathrm{CD} 38^{-}$and $\mathrm{CD} 19^{+} \mathrm{CD} 27^{++} \mathrm{CD} 38^{+++}$, respectively (reviewed in [7-9]). The process of generating MBCs and LLPCs begins when naïve B cells encounter their cognate antigen near the interface of $\mathrm{B}$ and $\mathrm{T}$ cell areas of secondary lymphoid tissue, which drives naïve $\mathrm{B}$

\section{Biomed Central}


cells to differentiate into isotype-switched short-lived, plasma cells (SLPCs) within the extra-follicular region, which contributes to the initial control of infections. Alternatively, naïve B cells enter follicles where germinal centers are formed, and after a period of 7-10 days, during which the $\mathrm{CD}^{+}{ }^{+} \mathrm{T}$-cell-dependent process of affinity maturation and immunoglobulin class-switching occurs, the germinal center reaction yields LLPCs and MBCs of higher affinity than the initial wave of SLPCs. LLPCs migrate to the bone marrow where they constitutively secrete antibody and provide a critical first line of defense against re-infection, whereas MBCs recirculate and mediate recall antibody responses after re-exposure to their cognate antigen by rapidly proliferating and differentiating into plasma cells.

Recently, it was reported that P. falciparum exposure in Malian children and adults, as well as Peruvian adults [10], is associated with an expansion of a phenotypically distinct population of $\mathrm{MBCs}$ identified as $\mathrm{CD} 10^{-} \mathrm{CD} 19^{+}$ CD20 ${ }^{+} \mathrm{CD}_{21}^{-} \mathrm{CD}^{-} 7^{-}$, similar to a $\mathrm{MBC}$ subpopulation initially identified in healthy US individuals in mucosalassociated lymphoid tissues by expression of the inhibitory receptor Fc-receptor-like-4 (FCRL4) [11]. B cells with a similar phenotype have been identified in individuals infected with HIV [12] and HCV [13]. Moir et al showed that compared to naïve $B$ cells and classical MBCs, FCRL4 ${ }^{+}$MBCs proliferated less well in response to BCR-cross-linking and/or to CD40L and Toll-like receptor 9 (TLR9) agonist CpG, and showed a decreased ability to differentiate into antibody secreting cells in response to polyclonal stimulation [12]. FCRL4 ${ }^{+}$MBCs in HIV-viremic [12] and P. falciparum-exposed individuals [11] also express high levels of inhibitory receptors and a profile of lymphoid-homing receptors similar to that expressed on exhausted $\mathrm{CD}^{+} \mathrm{T}$ cells during chronic viral infections [14]. Given that the function of FCRL4 ${ }^{+}$ MBCs in P. falciparum-exposed individuals is unknown, we refer to this B cell subset in the context of malaria as 'atypical' rather than 'exhausted'.

Here, the proportion of peripheral blood B cells that are immature and naïve B cells; plasma cells; and classical, activated, and atypical MBCs are compared in Fulani and Dogon adults [1], and further comparisons of these B cell subsets in asymptomatic $P$. falciparum infected and uninfected individuals from both ethnic groups are presented.

\section{Methods}

\section{Mali study site and participants}

This cross-sectional study was done in October 2008 in Mantéourou, Mali, a rural village approximately $850 \mathrm{~km}$ north of the capital of Bamako. A detailed description of the study site has been published elsewhere [1]. Participants were randomly selected from an ongoing cohort study which has been described in detail elsewhere [1]. Plasmodium falciparum transmission is seasonal and intense at this site from July through December. The entomological inoculation was approximately 17 infective bites/person/month in September of 2000. This crosssectional study includes 50 adults enrolled in October 2008. As is typical in Mali, the P. falciparum-infected adults had no signs or symptoms of malaria when the blood smear was prepared and they were not treated with anti-malarial drugs (the blood smear was not read immediately). The Ethics Committee of the Faculty of Medicine, Pharmacy, and Odonto-Stomatology at the University of Bamako, Mali approved this study. Deidentified specimens were obtained from this study for immunological analyses. Written, informed consent was obtained from all study participants.

\section{U.S. blood donors}

Peripheral blood mononuclear cells (PBMCs) from eight healthy adult blood bank donors in the U.S. were also analysed. Demographic and travel history data were not available from these anonymous donors but prior $P$. falciparum exposure is unlikely. Blood samples were obtained for research use after written informed consent was obtained from all study participants enrolled in a protocol approved by the Institutional Review Board of the National Institute of Allergy and Infectious Diseases, NIH (protocol \# 99-CC-0168).

\section{PBMC isolation, cryopreservation, and recovery}

Malian blood samples were drawn by venipuncture into sodium citrate-containing cell preparation tubes (BD, Vacutainer CPT Tubes). PBMCs were isolated according to the manufacturer's instructions and frozen in foetal bovine serum (FBS) (Gibco, Grand Island, NY) containing 7.5\% dimethyl sulfoxide (DMSO; Sigma-Aldrich, St. Louis, MO). U.S. blood samples were drawn into heparinized tubes $(\mathrm{BD})$ and $\mathrm{PBMC}$ were isolated from whole blood by Ficoll-Hypaque density gradient centrifugation (Amersham Biosciences) according to the manufacturer's instructions, and frozen in same conditions as Malian samples. PBMCs were kept at $-80^{\circ} \mathrm{C}$ for 24 hours using freezing containers (VWR International) to control the rate of freezing and then transferred to liquid nitrogen. For analysis, PBMCs were rapidly thawed in a $37^{\circ} \mathrm{C}$ water bath, washed first in PBS with 10\% heat-inactivated FBS and then in complete RPMI (RPMI 1640 with L-glutamine supplemented with $10 \%$ heat-inactivated FBS, penicillin/ streptomycin $10,000 \mu \mathrm{g} / \mathrm{ml}$, and $50 \mu \mathrm{M} \beta$-mercaptoethanol (all from GIBCO, Invitrogen)).

\section{B cell phenotypic analysis}

PBMCs were washed in PBS with $4 \%$ heat-inactivated FBS and incubated for $30 \mathrm{~min}$ at $4^{\circ} \mathrm{C}$ with mouse 
monoclonal fluorescently-labeled antibodies specific for CD10 APC (HI10a) and CD20 APC-H7 (L27) (BD Biosciences); CD19 PerCP-Cy5.5 (SJ25C1) and CD27 PE-Cy7 (O323) (eBioscience) and CD21 FITC (BL13) (Beckman Coulter). Flow cytometry was performed with a $\mathrm{BD}^{\mathrm{TM}}$ LSR II Table flow cytometer (BD Biosciences) and data were analysed using FlowJo software (Tree Star, Inc).

\section{Measurement of peripheral blood $P$. falciparum parasitaemia}

Thick blood smears were stained with Giemsa and counted against 300 leukocytes. Plasmodium falciparum densities were recorded as the number of asexual parasites/ $\mu$ l of whole blood based on an average leukocyte count of $7,500 / \mu \mathrm{l}$. Each smear was evaluated separately by two expert microscopists. Any discrepancies were resolved by a third expert microscopist.

\section{Statistical analysis}

Data were analysed using GraphPad Prism 5 for Mac OS X (GraphPad Software, version 5.0d). The non-parametric Mann-Whitney test was used to compare continuous variables between groups, and the Fisher's exact test was used to compare categorical variables. For all tests, twotailed $\mathrm{p}$ values were considered significant if $\leq 0.05$.

\section{Results and discussion}

\section{Study subject characteristics}

Twenty-five Fulani adults and 25 Dogon adults living in the same village in Mali were included in this study. Demographic and P. falciparum infection status data are shown in Table 1 according to ethnic group. The average age of the Fulani participants was 38.9 years (range: $19-57$ years) and 60\% were female. The average age of the Dogon participants was 38.0 years (range: 21-57 years) and 36\% were female. At the time of the venous blood collection, four Fulani (16\%) and nine Dogon (36\%) were infected with P. falciparum by bloodsmear. Of those who were infected, the mean parasite densities for the Fulani and Dogon were 2281.25 \pm 1285.9

Table 1 Age and gender distribution of participants by ethnic group, parasite prevalence and parasite density at the time of venous blood collection

\begin{tabular}{lccc}
\hline & Fulani & Dogon & P value \\
\hline Number of subjects & 25 & 25 & \\
Age-range (years) & $21-57$ & $22-57$ & \\
Age-median (years) & 37 & 38 & ns 0.777 \\
$\begin{array}{l}\text { Gender distribution } \\
\text { (\% women) }\end{array}$ & 36 & 52 & ns 0.138 \\
Parasite prevalence (\%) & 16 & 36 & ns 0.196 \\
$\begin{array}{l}\text { Parasite density }+/- \\
\text { SD (parasites } / \mu l)\end{array}$ & $2281.25 \pm 1285.9$ & $2563.5 \pm 1652.9$ & ns 0.766 \\
\hline
\end{tabular}

and $2563.5 \pm 1652.9$ asexual parasites/ $\mu$ l, respectively. All participants were afebrile and asymptomatic at the time of venous blood draw.

\section{Phenotypic analysis of B cell subsets}

The proportion of various $B$ cell subsets in the peripheral blood of Fulani $(n=25)$ and Dogon $(n=25)$ adults was compared by flow cytometry analysis of thawed PBMCs, which had been collected at the peak of the malaria season. These data were compared to B cell profiles of $P$. falciparum-naïve U.S. adults $(n=8)$.

A panel of fluorophore-conjugated antibodies specific for CD10, CD19, CD20, CD21 and CD27 allowed for the quantification of immature $\mathrm{B}$ cells $\left(\mathrm{CD} 10^{+} \mathrm{CD} 19^{+}\right)$, naïve $\mathrm{B}$ cells $\left(\mathrm{CD} 10^{-} \mathrm{CD} 19^{+} \mathrm{CD} 20^{+} \mathrm{CD} 21^{+} \mathrm{CD} 27^{-}\right)$, plasma cells/ plasma blasts $\left(\mathrm{CD} 10^{-} \mathrm{CD} 19^{+} \mathrm{CD} 20^{-} \mathrm{CD} 21^{-} \mathrm{CD} 27^{+}\right)$, classical MBCs $\left(\mathrm{CD} 10^{-} \mathrm{CD} 19^{+} \mathrm{CD} 20^{-} \mathrm{CD} 21^{+} \mathrm{CD} 27^{+}\right)$, activated MBCs $\left(\mathrm{CD} 10^{-} \mathrm{CD} 19^{+} \mathrm{CD} 20^{+} \mathrm{CD} 21^{-} \mathrm{CD} 27^{+}\right.$) and atypical MBCs $\left(\mathrm{CD} 10^{-} \mathrm{CD} 19^{+} \mathrm{CD} 20^{+} \mathrm{CD} 21^{-} \mathrm{CD} 27^{-}\right)$. Figure 1 shows the gating strategy used to identify these $\mathrm{B}$ cell subpopulations in a representative Fulani adult.

As a percentage of total lymphocytes, the mean percentage of total B cells $\left(\mathrm{CD} 19^{+}\right)$was similar in Fulani and Dogon adults (Figure 2A; Fulani: 13.6\% [95\% CI: 11.3 - 15.94]; Dogon: 14.2\% [95\% CI: 11.86 - 16.60], but significantly lower than U.S. adults (Figure 2A; U.S.: 34.8\% [95\% CI: 26.56 - 42.96]; p $<0.001$ versus Fulani and Dogon). As a percentage of total B cells, the mean percentages of immature B cells (Figure 2B; Fulani: 2.066\% [95\% CI: 1.452 - 2.679]; Dogon: 1.514\% [95\% CI: 1.2 - 1.829] and naïve B cells (Figure 2C; Fulani: 35.6\% [95\% CI: 31.55 - 39.63]; Dogon: 39.4\% [95\% CI: 35.33 43.52] were also similar between the Fulani and Dogon, but lower than U.S. adults (Figure $2 \mathrm{~B}$ and 2C; U.S. immature B cells: 5.023\% [95\% CI: 3.212 - 6.833]; U.S. naïve B cells: 79.6\% [95\% CI: 66.53 - 92.65]; p $<0.001$ for all comparisons). The mean percentage of plasma cells/plasma blasts was also similar among Fulani and Dogon adults (Figure 2D; Fulani: 1.95\% [95\% CI: 1.537 2.371]; Dogon: 2.0\% [95\% CI: 1.616 - 2.391], but higher than U.S. adults (Figure 2D; U.S.: 0.3188\% [95\% CI: 0.1656-0.4720]; $\mathrm{p}<0.001$ versus Fulani and Dogon). The mean percentage of classical MBCs did not differ significantly across the three groups (Figure 2E; Fulani: 25.08\% [95\% CI: 20.84 - 29.32]; Dogon: 22.97\% [95\% CI: 19.3 - 26.64]; U.S.: 16.12\% [95\% CI: 6.25 - 25.99]). Interestingly, the mean percentage of activated MBCs was significantly higher in Fulani versus Dogon adults (Figure 2F; Fulani: 11.07\% [95\% CI: 9.317 - 12.82]; Dogon: 8.31\% [95\% CI: 6.378 - 10.23]; $\mathrm{p}=0.016$ ) and both groups were higher than U.S. adults (Figure 2F; U.S.: 1.32\% [95\% CI: $0.011-2.63$ ]; $\mathrm{p}<0.001$ versus Fulani and Dogon). Finally, the mean percentage of atypical MBCs was similar among Fulani and Dogon adults (Figure 2G; 

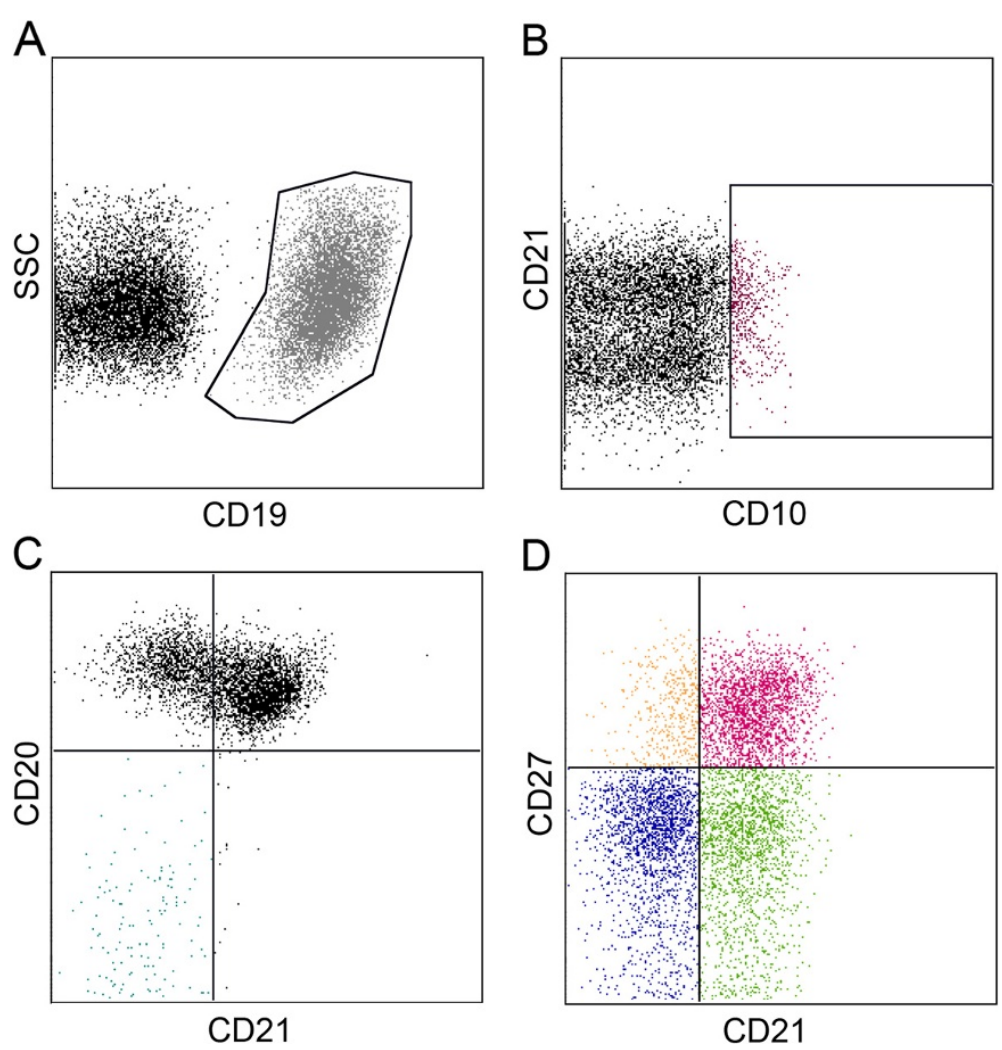

Figure 1 Flow cytometry gating strategies for B cell phenotyping. FACS plots of B cell subsets of a representative Fulani adult. Within the $\mathrm{CD} 19^{+}$gate shown in gray (A), the B cell subpopulations are defined as follows: immature $\left(\mathrm{CD} 10^{+}\right)$shown in purple (B); plasma cells/plasma

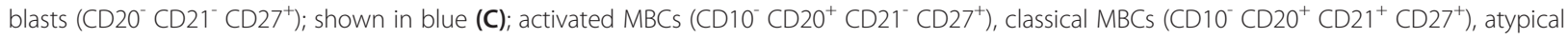
MBCs (CD10- CD20 ${ }^{+}$CD21- CD27) and naïve B cells (CD10- CD20 ${ }^{+}$CD21 ${ }^{+}$CD27) shown in orange, pink, blue and green respectively (D).

Fulani: 28.3\% [95\% CI: 22.73 - 34.88]; Dogon: 29.3\% [95\% CI: 25.06 - 33.55], but higher than U.S. adults (Figure 2G; U.S.: $3.0 \%$ [95\% CI: $-0.21-6.164]$; $\mathrm{p}<0.001$ versus Fulani and Dogon).

Together these data indicate that the overall distribution of B cell subsets is similar among the Fulani and Dogon adults in this study population, with the exception of activated MBCs, which were increased among the Fulani. Activated MBCs are known to promote signaling cascades that induce their differentiation into antibody secreting cells, thus a higher level of activated MBCs among the Fulani is consistent with their propensity toward higher antibody responses and decreased malaria susceptibility [2,6].

The higher percentage of atypical and activated MBCs in Fulani and Dogon Malians versus U.S. adults is consistent with previous studies of $P$. falciparum-exposed individuals at separate study sites in Mali [11], in The Gambia [15], and Peru [10]. These data provide further evidence that an increase in atypical MBCs is a generalizable finding among $P$. falciparum-exposed populations. The specificity and function of atypical
MBCs in the context of $P$. falciparum transmission remains to be determined. It is possible that atypical $\mathrm{MBCs}$ contribute to protection against malaria by regulating the host immune response; on the other hand, it is also conceivable that functional exhaustion of P. falciparumspecific MBCs through repeated infections contributes to the inefficient acquisition and relatively rapid loss of P. falciparum-specific MBCs and long-lived antibodies which has been observed in areas of intense P. falciparum transmission [16,17].

Also consistent with previous observations [10,11,16], it was found that relative to U.S. volunteers, Malian adults had a lower proportion of immature and naive $B$ cells and a higher proportion of activated MBCs and plasma cells/plasmablasts, possibly reflecting greater $\mathrm{cu}-$ mulative immunological experience.

To assess whether concurrent asymptomatic P. falciparum infection was associated with alterations in B cell subsets, Fulani and Dogon adults were stratified by whether or not the thick blood smears were positive for $P$. falciparum infection at the time of blood collection. Plasmodium falciparum infection status was not 

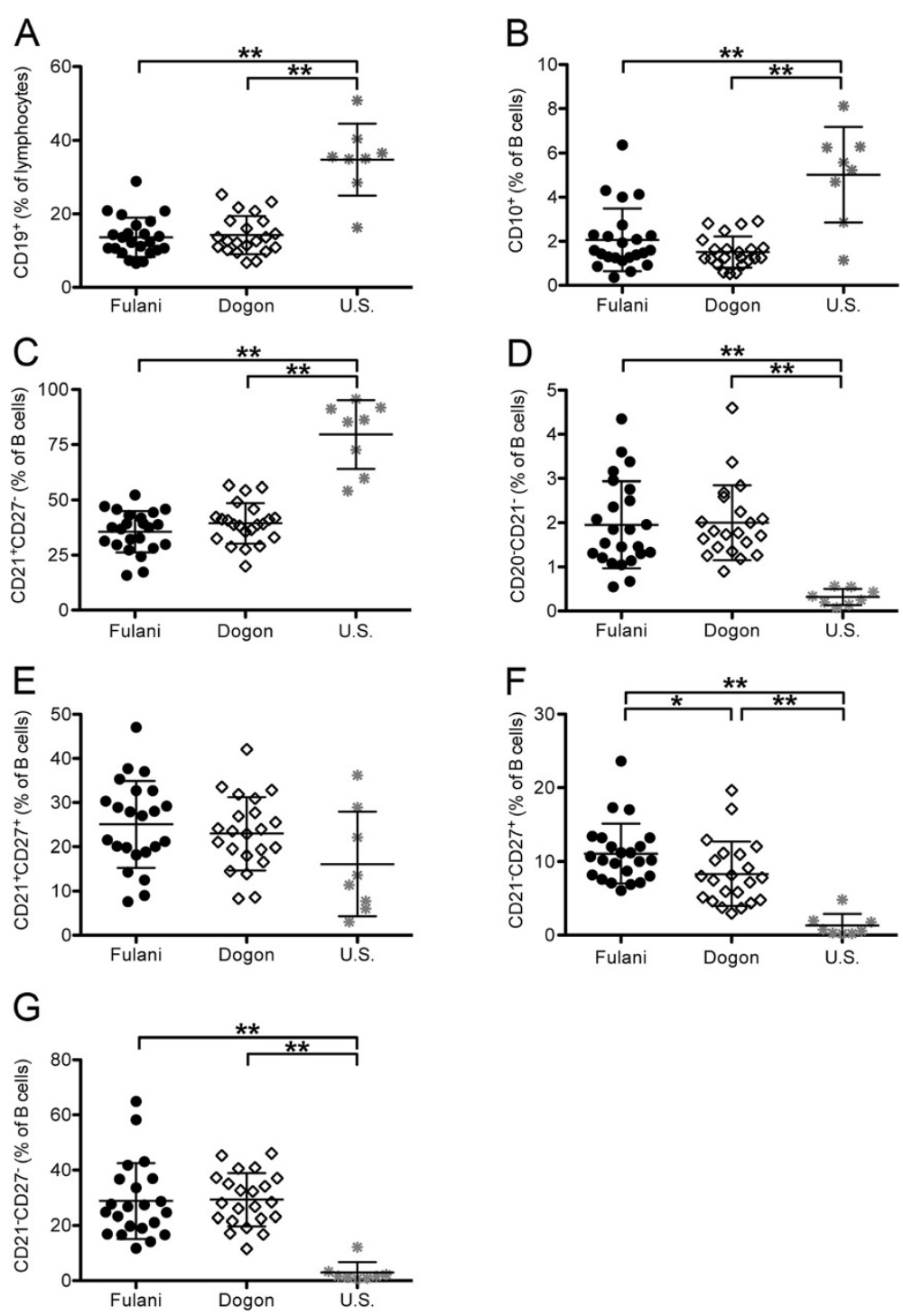

Figure 2 B cell populations of Fulani, Dogon and U.S. volunteers. PBMCS from Fulani, Dogon and U.S. volunteers were analysed by flow-cytometry. Quantitation of total B cells $\left(C D 19^{+}\right)(\mathbf{A})$, immature B cells $\left.\left(C D 10^{+} \text {CD19 }\right)^{+}\right)(\mathbf{B})$, naïve B cells $\left(C D 21^{+}\right.$CD27) $(\mathbf{C})$, plasma cells/plasma blasts (CD20- CD21) (D), classical MBCs $\left(C D 21^{+}\right.$CD27 $)(\mathbf{E})$, activated MBCs (CD21- CD27 $)$ (F) and atypical MBCs (CD21 CD27) (G). N=25 for Fulani and Dogon volunteers and $n=8$ for U.S. volunteers. Lines represent mean \% of live lymphocytes; error bars indicate SD $\left(^{*} p<0.05\right.$; $\left.{ }^{* *} p<0.001\right)$.

associated with significant differences in the percentages of total B cells (Figure 3A). However, P. falciparum infection was associated with a lower percentage of immature B cells among the Fulani (Figure 3B; Fulani uninfected: $2.336 \%$ [95\% CI: 1.656 - 3.016]; Fulani infected: $0.7803 \%$ [95\% CI: 0.167 - 1.393]; $\mathrm{p}=0.005$ ), but not the Dogon (Figure 3B; Dogon uninfected: 1.505\% [95\% CI: 1.029 - 1.982]; Dogon infected: $1.428 \%$ [95\% CI: 0.9207 - 1.935]). Plasmodium falciparum infection was not associated with significant differences in the percentage of naïve B cells in either ethnic group (Figures 3C), while P. falciparum infection was associated with a significantly higher percentage of plasma cells/ plasma blasts in the Fulani (Figure 3D; Fulani uninfected: 1.71\% [95\% CI: 1.33 - 2.08]; Fulani infected: 3.3\% [95\% CI: 1.788 - 4.744]; $\mathrm{p}=0.011$ ), but not the Dogon (Figure 3D; Dogon uninfected: $2.17 \%$ [95\% CI: 1.549 - 2.799]; Dogon infected: $1.81 \%$ [95\% CI: 1.276 - 2.536]). The higher percentage of antibody-secreting plasma cells observed in P. falciparum-infected Fulani adults is consistent with the higher levels of $P$. falciparum-specific antibodies observed by others in this ethnic group [2-4]. Asymptomatic $P$. falciparum infection was not associated with significant changes in the percentages of 

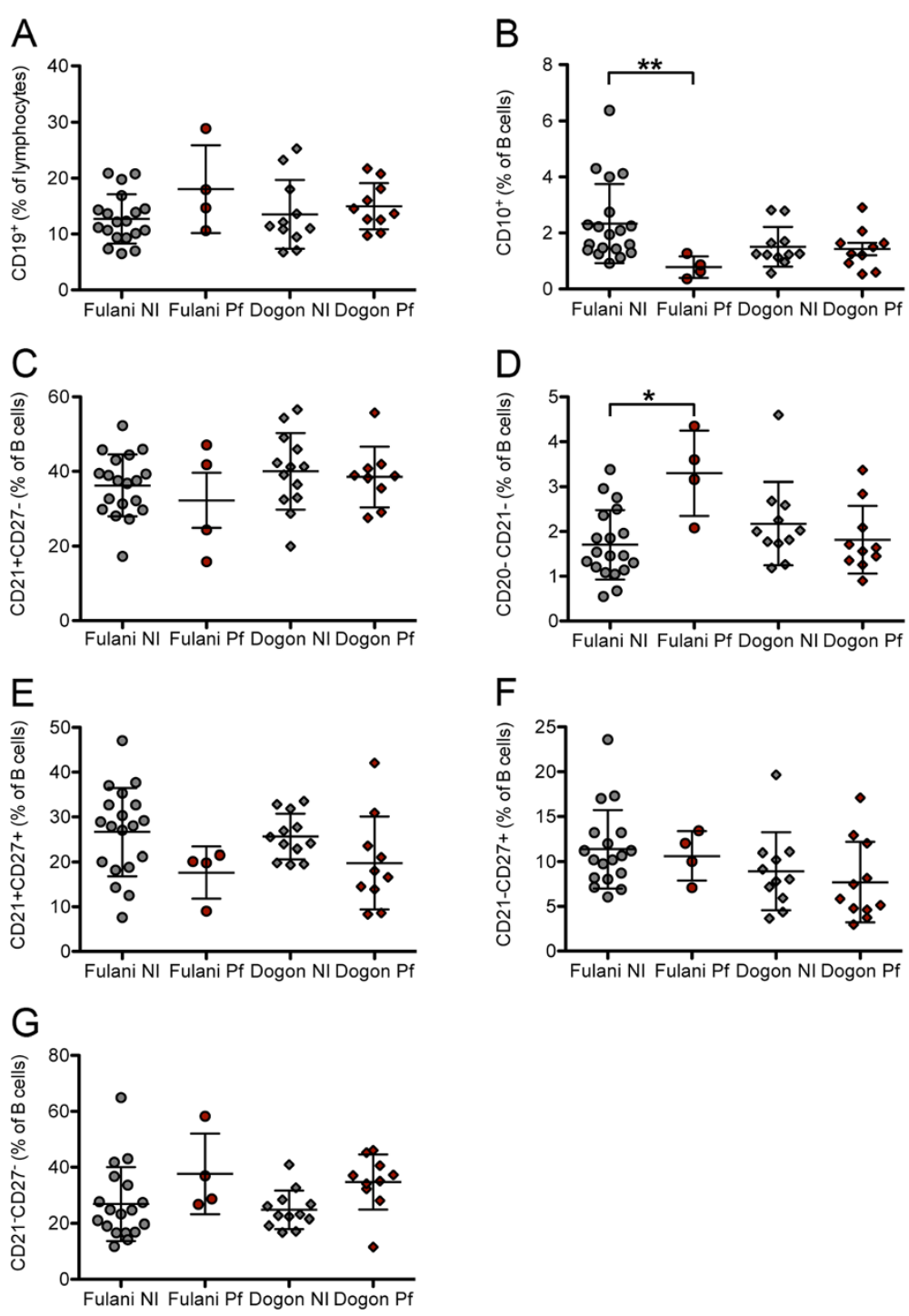

Figure 3 B cell populations from P. falciparum-infected Fulani and Dogon volunteers. PBMCs from P. falciparum-infected Fulani, Dogon and U. S. volunteers were analyzed by flow-cytometry. Quantitation of total B cells $\left(C D 19^{+}\right)(\mathbf{A})$, immature B cells $\left(C D 10^{+}\right.$CD19 $)(\mathbf{B})$, naïve B cells $\left(C D 21^{+}\right.$CD27) (C), plasma cells/plasma blasts (CD20 CD21) (D), classical MBCs (CD21 $\left.{ }^{+} \mathrm{CD} 27^{+}\right)(\mathbf{E})$, activated MBCs $\left(\mathrm{CD} 21^{-} \mathrm{CD} 27^{+}\right)(\mathbf{F})$, and atypical MBCs $\left(\mathrm{CD} 21^{-} \mathrm{CD} 27^{-}\right)$ (G). $N=4$ infected Fulani; $n=9$ infected Dogon. Lines represent mean \% of live lymphocytes; error bars indicate SD $\left(^{*} p<0.05 ;{ }^{* *} p<0.01\right)$.

classical, activated or atypical MBCs in either ethnic group (Figures 3E-G).

\section{Conclusion}

It is well established that the Fulani ethnic group is less susceptible to malaria compared to other sympatric ethnic groups in West Africa, but the mechanisms underlying this observation remain obscure. The enhanced $P$. falciparum-specific antibody response of the Fulani group is among the more consistent observations, which led us to investigate potential differences in B cell subpopulations. Indeed, the Fulani had a higher percentage of activated MBCs compared to the Dogon, and that $P$. falciparum infection was associated with higher percentage of antibody-secreting cells among the Fulani but not the Dogon. These results serve as a basis for further studies of the B cell biology that underlies the association between Fulani ethnicity and decreased malaria susceptibility.

\section{Competing interests}

The authors declare that they have no competing interests.

\section{Authors' contributions}

SP designed and carried out the flow cytometry, analysed the data, and drafted the manuscript. DD participated in the design and coordination of 
the study in Mali and analysed the clinical data. BT, LHM, MTB, OKD and AD conceived of the study and participated in its design and coordination in Mali. SKP and PDC conceived of the study, participated in its design and coordination in Mali, and helped to analyse the data and draft the manuscript. All authors read and approved the final manuscript.

\section{Acknowledgements}

We sincerely thank the residents of Mantéourou, Mali for their participation in this study. We also thank Dr. Richard Sakai and the staff of the Mali Service Center in Bamako for logistical support. This work was supported by the Division of Intramural Research of the National Institute of Allergy and Infectious Diseases, National Institutes of Health and by BioMalPar consortium project. SP is supported by a European Molecular Biology Organization long-term fellowship.

\section{Author details}

'Laboratory of Immunogenetics, National Institute of Allergy and Infectious Diseases, National Institutes of Health, Rockville, MD 20852, USA. Malaria Research and Training Centre, Department of Epidemiology of Parasitic Diseases, Faculty of Medicine, Pharmacy, and Odonto-Stomatology, University of Bamako, Bamako, Mali. 'aboratory of Malaria and Vector Research, National Institute of Allergy and Infectious Diseases, National Institutes of Health, Rockville, MD 20852, USA. ${ }^{4}$ Department of Immunology, Wenner-Gren Institute, Stockholm University, Stockholm, Sweden.

Received: 13 March 2012 Accepted: 11 May 2012

Published: 11 May 2012

\section{References}

1. Dolo A, Modiano D, Maiga B, Daou M, Dolo G, Guindo H, Ba M, Maiga H, Coulibaly D, Perlman H, Blomberg MT, Toure YT, Coluzzi M, Doumbo O: Difference in susceptibility to malaria between two sympatric ethnic groups in Mali. Am J Trop Med Hyg 2005, 72:243-248.

2. Modiano D, Chiucchiuini A, Petrarca V, Sirima BS, Luoni G, Roggero MA, Corradin G, Coluzzi M, Esposito F: Interethnic differences in the humoral response to non-repetitive regions of the Plasmodium falciparum circumsporozoite protein. Am J Trop Med Hyg 1999, 61:663-667.

3. Modiano D, Petrarca V, Sirima BS, Bosman A, Nebie I, Diallo D, Lamizana L, Esposito F, Coluzzi M: Plasmodium falciparum malaria in sympatric ethnic groups of Burkina Faso, west Africa. Parassitologia 1995, 37:255-259.

4. Modiano D, Petrarca V, Sirima BS, Nebie I, Diallo D, Esposito F, Coluzzi M: Different response to Plasmodium falciparum malaria in west African sympatric ethnic groups. Proc Natl Acad Sci U S A 1996, 93:13206-13211.

5. Pandey JP, Nasr A, Rocca KM, Troy-Blomberg M, Elghazali G: Significant differences in GM allotype frequencies between two sympatric tribes with markedly differential susceptibility to malaria. Parasite Immunol 2007, 29:267-269.

6. Bolad A, Farouk SE, Israelsson E, Dolo A, Doumbo OK, Nebie I, Maiga B, Kouriba B, Luoni G, Sirima BS, Modiano D, Berzins K, Troye-Blomberg M: Distinct interethnic differences in immunoglobulin $\mathrm{G}$ class/subclass and immunoglobulin $\mathrm{M}$ antibody responses to malaria antigens but not in immunoglobulin $\mathrm{G}$ responses to nonmalarial antigens in sympatric tribes living in West Africa. Scand J Immunol 2005, 61:380-386.

7. Gourley TS, Wherry EJ, Masopust D, Ahmed R: Generation and maintenance of immunological memory. Semin Immunol 2004, 16:323-333.

8. Tarlinton DM: Evolution in miniature: selection, survival and distribution of antigen reactive cells in the germinal centre. Immunol Cell Biol 2008, 86:133-138.

9. Yoshida T, Mei H, Dorner T, Hiepe F, Radbruch A, Fillatreau S, Hoyer BF: Memory B and memory plasma cells. Immunol Rev 2010, 237:117-139.

10. Weiss GE, Clark EH, Li S, Traore B, Kayentao K, Ongoiba A, Hernandez JN, Doumbo OK, Pierce SK, Branch OH, Crompton PD: A positive correlation between atypical memory $B$ cells and Plasmodium falciparum transmission intensity in cross-sectional studies in Peru and Mali. PLoS One 2011, 6:e15983.

11. Weiss GE, Crompton PD, Li S, Walsh LA, Moir S, Traore B, Kayentao K, Ongoiba A, Doumbo OK, Pierce SK: Atypical memory B cells are greatly expanded in individuals living in a malaria-endemic area. $J$ Immunol 2009, 183:2176-2182.
12. Moir S, Ho J, Malaspina A, Wang W, DiPoto AC, O'Shea MA, Roby G, Kottilil S, Arthos J, Proschan MA, Chun TW, Fauci AS: Evidence for HIV-associated B cell exhaustion in a dysfunctional memory B cell compartment in HIV-infected viremic individuals. J Exp Med 2008, 205:1797-1805.

13. Charles ED, Green RM, Marukian S, Talal AH, Lake-Bakaar GV, Jacobson IM, Rice CM, Dustin LB: Clonal expansion of immunoglobulin M + CD27+ B cells in HCV-associated mixed cryoglobulinemia. Blood 2008, 111:1344-1356.

14. Sohn HW, Krueger PD, Davis RS, Pierce SK: FcRL4 acts as an adaptive to innate molecular switch dampening BCR signaling and enhancing TLR signaling. Blood 2011, 118:6332-6341.

15. Nogaro SI, Hafalla JC, Walther B, Remarque EJ, Tetteh KK, Conway DJ, Riley EM, Walther M: The breadth, but not the magnitude, of circulating memory $\mathrm{B}$ cell responses to $\mathrm{P}$. falciparum increases with age/exposure in an area of low transmission. PLoS One 2011, 6:e25582.

16. Weiss GE, Traore B, Kayentao K, Ongoiba A, Doumbo S, Doumtabe D, Kone Y, Dia S, Guindo A, Traore A, Huang CY, Miura K, Mircetic M, Li S, Baughman A, Narum DL, Miller LH, Doumbo OK, Pierce SK, Crompton PD: The Plasmodium falciparum-specific human memory B cell compartment expands gradually with repeated malaria infections. PLoS Pathog 2010 6:e1000912.

17. Crompton PD, Kayala MA, Traore B, Kayentao K, Ongoiba A, Weiss GE, Molina DM, Burk CR, Waisberg M, Jasinskas A, Tan X, Doumbo S, Doumtabe D, Kone $Y$, Narum DL, Liang X, Doumbo OK, Miller LH, Doolan DL, Baldi P, Felgner $\mathrm{PL}$, Pierce SK: A prospective analysis of the $\mathrm{Ab}$ response to Plasmodium falciparum before and after a malaria season by protein microarray. Proc Natl Acad Sci U S A 2010, 107:6958-6963.

doi:10.1186/1475-2875-11-162

Cite this article as: Portugal et al:: B cell analysis of ethnic groups in Mali with differential susceptibility to malaria. Malaria Journal 2012 11:162.

\section{Submit your next manuscript to BioMed Central and take full advantage of:}

- Convenient online submission

- Thorough peer review

- No space constraints or color figure charges

- Immediate publication on acceptance

- Inclusion in PubMed, CAS, Scopus and Google Scholar

- Research which is freely available for redistribution

Submit your manuscript at www.biomedcentral.com/submit
C) Biomed Central 